\title{
SOCIAL CHANGE AND FRAGMENTED COHESION \\ (Case Study of Muslim Family Relations in Bogor City, West Java)
}

\author{
JM Muslimin \\ State Islamic University Syarif Hidayatullah Jakarta \\ Ciputat Timur, Kota Tangerang Selatan, Banten 15419 \\ E-mail:jm.muslimin@uinjkt.ac.id \\ Laila Setyawati Arifin \\ State Islamic University Syarif Hidayatullah Jakarta \\ Ciputat Timur, Kota Tangerang Selatan, Banten 15419 \\ E-mail:faradesha@gmail.com \\ Wildan Munawar \\ Djuanda University Bogor \\ Ciawi, Bogor, Jawa Barat 16720 \\ E-mail: wildan.munawar@unida.ac.id \\ Mahmoud Mohamed Hosny Mohamed \\ Al-Azhar University Cairo \\ Nazlet Al Batran, Al Haram, Giza Governorate, Egypt \\ E-mail:mahmoudalazbi89@gmail.com
}

\begin{tabular}{c|c|c}
\hline Received: & Revised: & Approved: \\
10/11/2019 & $05 / 10 / 2020$ & $25 / 11 / 2020$ \\
\hline
\end{tabular}

DOI: $10.32332 /$ akademika.v25i2.2477

\begin{abstract}
Entering the era of industrialization, humans live runs more pragmatically and individually. As part of gender studies, family constellation is being necessary to investigate. A significant impact can be seen from the estrangement that occurs in family relations. Family ties are felt to be increasingly loose because each person is required to have specific duties and professions to meet their needs. As a result, transformation and social change make it increasingly difficult to create intimacy like the past. The purpose of this study is to analyze the impact of social transformation on proposed divorce (cerai gugat) by wife, which is more common than divorce and social changes in family relations. The research is done by combining empirical approach and normative one. The empirical data gathered from several sources and referred to strengthen normative postulate. Where as the normative postulate is drafted to be starting point of the research. The results of this study indicate that the
\end{abstract}


causes of social transformation in divorce are increased lawsuit divorce due to nushuz: wife disobedience to husband or lack of wife in carrying out their rights and obligations. Thus, increased divorce due to syiqaq: husband and wife's quarreling.

Keywords: Proposed divorce, social change, and family relation

\section{A. Introduction}

Muslim communities in Indonesia are now experiencing challenges in family life. Throughout 2018, a total of 419,268 couples decided to divorce. The most divorce initiatives came from women, totaling 307,778 women. ${ }^{1}$ In comparison, there were 111,490 from male parties. ${ }^{2}$ It is undeniable that marriages end in divorce for various reasons. It ranged from economic problems, infidelity, polygamy, inevitable differences of opinion, to the spouse's health problems. Harmonization between husband and wife fades, and as the times develop, the meaning of rights and obligations between the two is ignored. This happened in Indonesia.

Currently, divorce is not considered taboo. The existence of social transformation from the perspective of marriage affects the attitude of a husband and wife in making decisions even though marriage is a gate of worship. ${ }^{3}$

Parental separation has an adverse impact on children, especially in the child's social and emotional development. ${ }^{4}$ Divorce has a greater impact on psychological problems, even if it is compared to the effect of the death of a parent. Because children still have the right to get attention, love, and encouragement from their parents even though the parents are separated.

1 Mufliha Wijayati dan Aden Rosadi, "Women Before The Law: Between Justice and Certainty: Notes on Divorce Settlement Case Due to Domestic Violencein Metro Religious Court," AKADEMIKA: Jurnal Pemikiran Islam 25, no. 1 (Juni 2020): 209-34, https://doi.org/10.32332/akademika.v25i1.1974

2 https://www.mahkamahagung.go.id/id accessed 20 January 2020.

3 Hammudah Abd Al-Ati, Family Structure in Islam, (American Trust Publication, 1977), p. 54.

${ }^{4}$ John Gottman, Joan De Claire, Mengembangkan Kecerdasan Emosional Anak, (Jakarta: PT. Gramedia Pustaka Utama, 2008), p. 160. 
Nevertheless, unfortunately, many husbands and wives divorce without thinking about their offspring. Thus, it has a tremendous impact on children's growth and development. The impact of divorce is of various kinds, including straining kinship relationships, breaking the family from the relationship of marriage, and the baby being the worst victim that will affect his life. ${ }^{5}$ Divorce should also be viewed as a safeguard when tensions arise in the marriage itself, even though it looks terrible in social and religious status. It is the positive side of divorce. ${ }^{6}$

The Complication of Islamic Law (Kompilasi Hukum Islam) states that divorce is known by two types: divorce and accountability (lawsuit divorce). Lawsuit divorce in the context of Islamic law is divorce, which is filed by the wife. Article 132 paragraph 1 Kompilasi Hukum Islam reads: "A divorce claim is filed by his wife or proxy at the Religious Court, whose jurisdiction covers the plaintiff's residence unless the wife leaves the residence without the husband's permission". While divorce as written in Kompilasi Hukum Islam Article 114, reads: "The termination of marriage due to divorce can occur because of divorce or based on lawsuit divorce." What is meant by divorce is the husband's statement before the Religious Court, which is the cause of divorce. Divorce in Islam is to break the bonds or dissolution of marital relations.

This research is field research with descriptive-analysis and critical analysis types of research using the legislative approach, case approach, and philosophical approach (combining empirical and normative approaches). The theory used is the theory of social transformation.

\section{B. Divorce from Islamic Legal Perspective}

Divorce in Islam is something that is hated even though it is lawful to do so. Rasulullah SAW hadith says:

"The thing that is lawful but which Allah hates is divorce".

According to Yusuf Qardhawi, divorce that comes from a husband is namely talak. He said that talak is a relief (rukhsah) that occurs because of an emergency, namely because the husband and wife relationship worsens,

5 Armansyah Matondang, "Faktor-faktor yang Mengakibatkan Perceraian dalam Perkawinan," JPPUMA: Jurnal Ilmu Pemerintahan dan Sosial Politik UMA (Journal of Governance and Political Social UMA) 2, no. 2 (1 Desember 2014): 141-50, https://doi.org/10.31289/jppuma.v2i2.919.

${ }^{6}$ Imani Jaafar-Mohammad dan Charlie Lehmann, "Women's Rights in Islam Regarding Marriage and Divorce," Journal of Law and Practice 4, no. 1 (1 Januari 2011): 1-13. 
and both want a divorce. ${ }^{7}$ In the past, divorce was like a prerogative that could be used anywhere and anytime. There were many cases of abuse of the authority of talak, also signs of using the sentence talak after the formation of contemporary family law. This means that the husband still has the right to divorce, but its use must be before the Religious Court hearing. ${ }^{8}$

In the break of the marital relationship, there is a right of the husband and the right of the wife. ${ }^{9}$ Divorce is the breaking up of a marriage at the husband's will for certain reasons and is stated by certain words. Meanwhile, khulu is the breaking of a marriage at the will of the wife. ${ }^{10}$ The wife also has the right to request that the husband is willing to divorce her even though the wife has to provide a fee whose amount is agreed by the husband. In another sense, the wife has the right to file for divorce by returning the dowry that her husband gave her ${ }^{11}$ or the amount of financing usually does not exceed the dowry ${ }^{12}$. This fee is interpreted as a ransom or iwadh. Khulu comes from Arabic that etymologically means to put clothes on or off.13 The Word of Allah SWT regarding khulu is contained in QS. al-Baqarah: 229. For Ibn Qudamah, the fiqh expert of the Hambali School, divorce is better for both. However, if the wife does not have an apparent reason, she should not ask for a divorce, because the Prophet Muhammad said: "If any woman asks her husband for divorce without some strong reason, the odor of Paradise will be forbidden to her."14

One of the causes of the emergence of a lawsuit divorce is the wife's nusyuz. Nusyuz, according to Hanafiyah is the wife leaving the house without her husband's permission and closing herself off to her husband, even though she has no right to do that. According to the Malikiyah scholars, nusyuz is when the wife is disobeying from the obligatory lines,

${ }^{7}$ Muhammad Yusuf Qardhawi, Halal Haram Dalam Islam, terj. Muammal Hamidi, (Surabaya: PT Bina Ilmu, 1980), p. 284.

${ }^{8}$ Mohammad Daud Ali, Hukum Islam dan Peradilan Agama, (Jakarta: PT. Raja Grafindo Persada, 2002), Cet ke-2, p. 105

${ }^{9}$ Achmad Kuzari, Nikah Sebagai Perikatan, (Jakarta: PT Raja GrafindoPersada, 1995), $1^{\text {st }}$ edition, p. 117

${ }^{10}$ Amir Syarifuddin, Hukum Perkawinan Islam di Indonesia: Antara Figh Munakahat dan Undang-Undang Perkawinan, (Jakarta: Prenada Media), p. 197. 191.

${ }^{11}$ Sayyid Sabiq, Figh Sunnah, (Kairo: Daar al-Fath, 2000), $1^{\text {st }}$ edition, vol.2, p

${ }^{12}$ Achmad Kuzari, Nikah Sebagai Perikatan, (Jakarta: PT Raja Grafindo Persada, 1995), $1^{\text {st }}$ edition, p. 12.

${ }^{13}$ Amir Syarifuddin, Garis-Garis Besar Fiqh, (Bogor: Kencana Prenada Media, 2003), $1^{\text {st }}$ edition, p. 124.

${ }^{14}$ HR. Abu Dawud: 2226, Darimi: 2270, Ibnu Majah 2055, Amad: 5/283, with sanad hasan. 
forbidding the husband to have fun with her, leaving the house without the husband's permission because she knows that the husband will not allow her, leaving Allah's rights such as not wanting to take a bath, pray, and fasting Ramadan and closing all doors to her husband.

Meanwhile, according to the Syafi'iyah scholars, nusyuz is the wife's disobedience to her husband and violations committed against Allah's provisions. ${ }^{15}$ Hambaliyah scholars define it as a violation committed by a wife against her husband on the provisions obliged to him of the rights of marriage.

In addition, one of the causes of divorce is a husband-wife argument called syiqaq. Syiqaq is a dispute between husband and wife. In this case, syiqaq in Indonesian terms is a continuous dispute. In this situation, syiqaq comes from disharmony between spouse that caused by quarreling and fighting continuously. ${ }^{16}$

\section{The Theory of Social Transformation}

The theory of social transformation in the form of the theory of evolution (evolutionary theory) shows that changes due to evolution affect the way people are organized, especially those related to work. The process of social transformation and change from an agrarian society to industrial society also brings changes in patterns of social relations such as relations of production, relations in the political world, and social-cultural relations. The patterns of social relations between community members become impersonal, the social distance between social groups seems to widen, the value of one's self-esteem also tends to decrease. Social differentiation in industrial societies is very complex, for example, in terms of age, gender, race, behavior, choice of clothing, attitudes, patterns of interaction, urban, rural situations and so on. There are two common sources of social deregulation, namely egotism and anomie. ${ }^{17}$ Deregulation of this type of egotism is defined as a social phenomenon that refers to the relationship between individuals and society, where individuals are relatively independent, independent, and not bound by society's rules. Often in such circumstances, the individual is less or challenging to manage. For example, unmarried people are more independent than those who are already married. An individual who has been married is bound in one

15 Shaleh bin Ghanim al-Sadlani, Nusyuz, Konflik Suami Istri dan Penyelesaiannya, p. 26- 27.

16 Sulaeman Jajuli, Fenomena Al-Syiqaq dalam Putusan Perkawinan di Pengadilan Agama Kota Bogor, (Bogor: 2016), p. 18.

17 S. Wisni Septiarti, "Transformasi Sosial Masyarakat Dalam Perspektif Strukturalisme - Fungsionalisme Suatu Tinjauan Sosiologis," Jurnal Cakrawala Pendidikan 3, no. XIII (1994): 127-38, https://doi.org/10.21831/cp.v3i3.9153 
kinship by their husband, wife, children, and even the surrounding community, their social control is stronger.

On the contrary, social deregulation originating from anomie circumstances, a social change that is fast becoming the cause of deviant behavior, especially by Emile Durkheim, is categorized as suicide. This deviant behavior occurs in situations where economic conditions are increasing or shrinking. When economic conditions began to increase, the community's level of aspirations (individuals) also increased as a result of the ideals that were not achieved, resulting in violations of norms or suicide. Vice versa, with a shrinking economic situation, will make these individuals feel frustrated, stressed, and fatal suicide.

A shift also occurs in the family norms from the extended family to the nuclear family. One example, children are no longer seen as bringing fortune (banyak anak banyak rejeki), but now children are seen as an economic "burden". In the past, in the countryside, my uncle and nephew, for example, were still considered close relatives and even nuclear families. Marriage between siblings also often occurs. However, due to urbanization and industrialization, urban communities are more closed to their families. Busy work, busy studying, and other activities hamper communication between siblings. Finally, it causes estrangement in family relationships.

The participation of women in the world of work is currently increasing. The shift in the role of members in the household has a positive and negative impact on the family's sustainability. For example, a wife works while her husband is unemployed at home. This might show inequality in a household given the income is perceived as the wife's right from the husband but is now changing roles with the husband. The problem that occurs is that the wife has a dual role in earning a living and educating her children. Ultimately, this dysfunction can lead to cracks in the household.

One of the social transformations that affect household life is that the number of divorcees is higher than divorce talak. The Minister of Women's Empowerment and Child Protection of the Republic of Indonesia, Yohana Yembise said, the occurrence of domestic violence and the unfair distribution of roles in building a family are still the dominant reasons why divorce cases in Indonesia mostly come from the wife's side.

\section{Impact of Social Transformation on Divorce}

In Bogor City, the number of divorces for divorce and suing is relatively high and continues to increase every year. Compared to the number of marriages that occur each year, the following is the data on the number of marriages and divorces attached to the Class 1A Religious Court in Bogor City from 2016 to 2019. 
Table. 1. Number of Marriage in Bogor City

\begin{tabular}{llllll}
\hline No & Sub-District & 2016 & 2017 & 2018 & 2019 \\
\hline 1 & South Bogor & 1384 & 1441 & 1510 & 1558 \\
2 & East Bogor & 622 & 655 & 715 & 719 \\
3 & North Bogor & 1305 & 1335 & 1410 & 1308 \\
4 & Center Bogor & 53 & 780 & 763 & 735 \\
\hline 5 & West Bogor & 1496 & 1609 & 1699 & 1685 \\
6 & Tanah Sareal & 1299 & 1415 & 1500 & 1455 \\
\hline & Total & 6722 & 7236 & 7597 & 7460 \\
\hline
\end{tabular}

Table 2. Divorce Cases in 2017-2019

\begin{tabular}{llll} 
Year & 2017 & 2018 & 2019 \\
Total & 385 & 393 & 392 \\
\hline
\end{tabular}

Table 3. Proposed Divorce Cases in 2017-2019

\begin{tabular}{llll}
\hline Year & 2017 & 2018 & 2019 \\
Total & 1332 & 1356 & 1354 \\
\hline
\end{tabular}

The number of divorces that occurred in Bogor City in 2017 was 1717. Continue to increase by 32 cases with a total number of 1749 in 2018. In 2019 the number decreased slightly by $0.17 \%$ with 1746 cases. Thus divorce that occurred in 2017 amounted to $23.7 \%$ and in 2018 amounted to $23,02 \%$. In 2019 it increased to $23.4 \%$.

Based on the percentage, the lawsuit divorce, which occurred in 2017 amounted to $71.09 \%$, while divorce was only around $28.9 \%$. The number of lawsuit divorce in 2018 became $71.01 \%$ while divorce $28.8 \%$. In 2019, lawsuit divorce was $71.05 \%$, and divorce was around $28.5 \%$. 
The significance of divorce and lawsuit divorce in Bogor City is still very volatile. But the fact is, lawsuit divorce is always more numerous than divorce. Therefore, it becomes the main point of research on why this happened. Because about 20, 30 years ago, divorce was still considered taboo, and divorce was mostly only filed from husband to wife. There was almost no lawsuit, especially ones caused by economic problems. During the time, the wife was very submissive and obedient to her husband.

Antiquity does not mean that people feel even prosperity. The problem for writers is not the inclusion of material but in the different attitudes found in the ancient wives and contemporary wives. Without blaming one party, the husband of ancient times was more responsible for his family despite living long distances with his partner.

Aspects of life have experienced a shift along with the development of technology and information today. Facts due to changing times are felt at present vary and occur in all aspects of life. If society is not open to information and transformation of times, civilization will be easily left behind. Increasing the quality of information obtained with various facilities also has a significant impact on life today. Whatever feels easy without the hassle. On the other hand, the ease of getting information is not as easy as meeting the needs. Most other communities are still depressed by the entanglement of increasing needs. Increasingly, needs are not worth the income.

The trend of changing trends in divorce as described above explains the various fundamental changes in the structure and awareness of society regarding the position of women in divorce. In conventional divorce behavior, women tend to occupy as objects - not to call them victims - of divorce. Now, that position has begun to shift. The majority of women occupy the role of a subject who controls the decision to divorce. The change in women's position from object to subject of divorce is most likely related to the large socio-economic access that women get. The independence of women in economic matters is assumed to be the trigger for divorce decisions. This is the basis for the view that women's economic independence will enable women to choose divorce as a rational action in resolving the marriage crisis.

In 2018 , the percentage of the male population was $2.8 \%$ higher than the number of women. However, if you refer to the table below, the high number of male residents does not necessarily increase the number of male workers. On the contrary, the more educated a woman is, the more people work when compared to the number of male workers. 
Table 4. Number of Civil Servants by Education Level and Gender

Level of Education $\quad 2017 \quad 2018$

\begin{tabular}{lrrrr}
\hline & Male & Female & Male & Female \\
SD & 199 & 3 & 180 & 2 \\
SLTP & 189 & 11 & 178 & 10 \\
SLTA & 1408 & 385 & 1332 & 358 \\
Diploma & & & & \\
I, II,III & 227 & 528 & 203 & 492 \\
S1, S2 & 1654 & 2788 & 1639 & 2714 \\
Total & 3677 & 3715 & 3532 & 3576 \\
\hline
\end{tabular}

This table shows the number of Civil Servants recorded in the Bogor City Regional Statistics 2019. From the results above, the number of women who work is more than men. The higher the level of education for women, the more the number who work as civil servants. From all levels of education, the number of working women increased by $1.2 \%$ than men in 2017 . Then in 2018 , the number of women who worked was $1.23 \%$ higher than the number of men.

The social transformation has also contributed to changing women's perceptions of divorce. Previously, divorce for a woman was taboo. She will automatically hold the title of widow which is considered low in social space. In addition, women who are divorced must also bear the material burden of fulfilling life's necessities. Therefore, it is rare for a wife to want a divorce, let alone file a divorce from her husband. However, over time this kind of mindset began to shift, especially in urban areas. Nowadays, a wife does not hesitate to file for divorce when her marriage life has issues, such as not being supported economically, receiving harsh treatment from her husband or other reasons.

In this case, the community does not care about the problem of which party is aggrieved, whether the wife is identical as the party that is oppressed because of filing for divorce or the husband who is the victim of divorce, it seems that cases of legal divorce will increase. This is supported by the 'legal umbrella' that women currently have as a refuge.

The legal umbrella used by women to fight for their own destiny in terms of marriage and divorce is the Islamic Law Compilation (KHI), which has been used as the main reference by the Religious Courts (PA) in deciding cases of Muslims, including divorce initiated by the wife (lawsuit divorce). 
Divorce is said to be valid after a court decision is legally binding ${ }^{18}$. In other words, the divorce must go through a court, not another institution. However, it is not easy to sue or ask for divorce in court. According to the law, there must be sufficient reasons so that the court can grant the divorce suit.

According to Paul Bohannan, divorce takes place through a process and goes through several stages. This means that divorce does not just happen, it is an end of the process preceded by certain events according to the conditions of the relationship of husband and wife. Preceded events such as acts of violence that may be started by one of the couples then the divorce process ensued so that each pair was ready to separate from one another.

Paul Bohannan classified the divorce process into several stages, which are: 19

1. Financial Divorce: the separation of a married couple because of financial matters. For example, not fulfilling household needs for his wife.

2. Co-parental Divorce: former husband and wife partner no longer have togetherness in educating their children, because they have lived apart.

3. Law Divorce: Divorce granted by a legal decision through the court (law divorce). For Muslim people, the religious court will issue decisions on divorce I, II and III as the legal basis for divorce between husband and wife.

4. Community Divorce: Spouse no longer communicate, relate or collaborate with their former spouses, in-laws or previous communities.

5. Psycho-Emotional Divorce: feel distant and there is no emotional connection as a husband and wife even though they live together physically.

6. Physical Divorce: a condition where each individual does not live in one house anymore and has distance himself from his former spouse.

${ }^{18}$ Article 39 paragraph 1 Law no. 1 of 1974 concerning Marriage "Divorce can only be carried out before the Court Session after the Court concerned has tried and failed to reconcile the two parties."

${ }^{19}$ Paul Bohannan, Divorce and After , (America: Doubleday Books, 1971), p. 371. 


\section{E. Basic Reason For Requesting Divorce}

Article 39 paragraph 2 Law no. 1 of 1974 concerning Marriage and Article 19 of Government Regulation No. 9 of 1975 concerning the Implementation of Law Number 1 of 1974 concerning Marriage also explains the reasons for requesting divorce, namely as follows:

1. There are parties (between husband or wife) who commit adultery or become drunkards, prostitutes, gamblers who are difficult to cure.

2. There are parties (between husband or wife) who leave the other party for two consecutive years, without valid reasons or without the permission of the other party and for other reasons beyond their means.

3. There are parties (between husband or wife) who receive a sentence of either being imprisoned for five years or receiving a heavier sentence after the marriage takes place.

4. There are parties (between husband or wife) who commit severe abuse or cruelty to the other party.

5. There are parties (between husband or wife) who suffer from a disease that results in the inability to carry out their obligations as husband and wife or with disabilities.

6. There are continuous quarrels and fights between husband and wife and there is no hope of living in harmony again in the household.

For those who are Muslims, there are two additional reasons for divorce besides the reasons above, as stipulated in Article 116 of the Compilation of Islamic Law, namely:

1. Husband violates $t a^{\prime} l i k$-talak. This occurs when a husband:

a. Left wife for two consecutive years

b. Or did not support the wife's livelihood for three consecutive months

c. Or hurt his wife's body

d. Or neglect his wife for six months in a row.

2. Apostasy or religious conversion that causes disharmony in the household. In other words, the judge will not grant divorce lawsuits other than the above reasons

\section{F. Interpersonal Relationship Triggers Divorce}

Divorce can arise due to several supporting factors. In Bogor City, according to data from the Bogor City Religious Court in 2019, several reasons for divorce are as follows:

Table 5. Factors Causing Divorce ${ }^{20}$

${ }^{20}$ Data Course: Bogor City Religious Court Class 1A 


\begin{tabular}{llllllllll}
\hline No & Factor & Jan- & Feb- & Mar- & Apr- & Mei & Jun- & Jul- & Total \\
& & 19 & 19 & 19 & 19 & 19 & 19 & 19 & \\
\hline 1 & Polygamy & 0 & 1 & 1 & 0 & 0 & 0 & 0 & 2 \\
2 & Drunk/Gambling & 0 & 1 & 0 & 0 & 0 & 0 & 0 & 1 \\
3 & Apostate & 1 & 0 & 0 & 0 & 2 & 0 & 0 & 3 \\
4 & Forced Marriage & 0 & 0 & 0 & 0 & 0 & 0 & 0 & 0 \\
5 & Economy & 26 & 14 & 26 & 31 & 24 & 6 & 15 & 142 \\
6 & Not Responsible & 13 & 7 & 14 & 17 & 7 & 7 & 12 & 77 \\
7 & Early Marriage & 0 & 0 & 0 & 0 & 0 & 0 & 0 & 0 \\
8 & Hurting Body & 0 & 3 & 5 & 1 & 0 & 1 & 1 & 11 \\
9 & Hurting Mental & 0 & 0 & 0 & 0 & 0 & 0 & 0 & 0 \\
10 & Punished by Law & 0 & 0 & 0 & 0 & 0 & 0 & 0 & 0 \\
11 & Physic Defect & 1 & 0 & 0 & 0 & 0 & 0 & 0 & 1 \\
& Politic Third & & & & & & & & \\
12 & Party & 0 & 0 & 0 & 0 & 0 & 0 & 0 & 0 \\
13 & Interference & 0 & 0 & 0 & 0 & 0 & 0 & 0 & 0 \\
14 & Out of harmony & 80 & 75 & 85 & 90 & 78 & 29 & 47 & 484 \\
& Total per month & 121 & 101 & 131 & 139 & 111 & 43 & 75 & 721 \\
\hline
\end{tabular}

\section{Economy}

The current economic conflict tends to be the cause of divorce. Therefore, economic factor is the second highest cause of divorce, with a percentage of $19.7 \%$. The economic stability of a family is indeed related to happiness in the household as well as the smooth running of business and income has an influence on the smooth running of household life. Thus it is clear that economic factors often become one of the problems in married life. ${ }^{21}$ This is in line with an informant's opinion, as quoted "That the average husband and wife who gets a divorce for economic reasons is because the husband's job is not permanent and because the husband is unemployed so that it causes his wife to earn a living."

\section{Out of Harmony}

In family life between husband and wife, a good relationship is required in the sense that a harmonious atmosphere is needed, namely by creating a relationship of mutual understanding, mutual care, mutual respect, and meeting each other's needs. Disharmony is one of them created

${ }^{21}$ Nurhadi Nurhadi dan Mawardi Dalimunthe, "Concept of Maqasyid Syariah Family Sakinah In The Al-Misbah Tafsir by Muhammad Quraish Shihab," AKADEMIKA: Jurnal Pemikiran Islam 24, no. 1 (18 September 2019): 165-86, https://doi.org/10.32332/akademika.v24i1.1619 
due to a lack of communication between husband and wife. Because disharmony occupies the highest level in the factors causing divorce, namely $68 \%$, husband and wife must try to stay away from these problems. Efforts to create a harmonious family that can be applied in the household, for example, getting to know and understanding both parties, the two parties helping each other and understanding each other, mutual respect between partners, always pleasing partners, overcoming problems together, always being frank, tolerant, and caring attitude between partners. ${ }^{22}$

Four different styles of conflict, based on the literature on marital conflict ${ }^{23}$, were represented. These were: first, a 'coercive' style where partners verbally attacked one another (blaming the other and defending their position); second, a 'wife demands - husband withdraws' style (where the wife demands more help from the husband and he doesn't want to discuss the issue); third, a 'husband demands - wife withdraws' style (where the husband is demanding change and his wife doesn't want to discuss the issue); and, fourth, a 'mutual' style (where the spouses listened to each other's point of view and responded with understanding). All of the conflicts ended at a similar point - with no resolution of the issue.

The following is data related to education and the possibility of divorce that occurred in 2019 in Bogor City.

Table 6. Divorce Spouse Statistic Based on Education Level

Education Statistics

From Applicant/Litigant

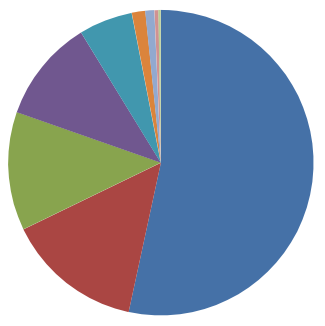

$$
\begin{aligned}
& \square \text { SLTA } \\
& \square \text { SLTP } \\
& \text { S1 } \\
& \text { SD } \\
& \text { D3 } \\
& \text { S2 }
\end{aligned}
$$

${ }^{22}$ Irma Yani dan Indrawati ", "Harmonisasi Keluarga Pasangan Suami Istri Yang Tidak Memiliki Keturunan Di Desa Bangun Jaya Kecamatan Tambusai Utara Kabupaten Rokan Hulu," Jurnal Online Mahasiswa (JOM) Bidang Ilmu Sosial Dan Ilmu Politik 5, no. 1 (3 Oktober 2017): 1-14.

23 Patricia Noller, Marital Conflict, Journal of Family Matters No.55 Autumn 2000, Australian Institute of Family Studies, p. 88. 
This shows that couples with high school education graduates currently rank first for divorce, with a total of 1050 people or $53 \%$. Followed by junior high school, namely 284 people or $14 \%$. It is undeniable that couples who hold the Srata-1 bachelor degree are enough to contribute a high number of around 247 people or $13 \%$. This level beats couples who only attend SD (Elementary School) around 214 people with $11 \%$ and Diploma 3 with 112 people or $6 \%$. Couples with a Strata-2 educational background are only around 28 people or $1 \%$, the same as couples with Diploma-1 degrees, namely 19 people. While the lowest result is $0 \%$, which amounts to 5 of the pairs who passed Diploma-2. This shows that the level of education does not guarantee every couple to divorce.

The difference between the results of the survey by the Bogor City Religious Court and the reality that occurs in the people of Bogor City only depends on a series of factors that cause divorce. If there is only one factor, for example, Drunk or Gambling, then the survey results also calculate that factor into the Drunk / Gambling table. However, if the factors are multiple, for example, at first there is a lack of income, then they are not responsible, resulting in disharmony, then the three are still reoccurring. All of these reasons or factors will certainly give a conclusion "not harmonious" even though the first or both factors have various reasons.

The Bogor City Government has not been able to reduce the divorce rate and maintain its people's household resilience. Back in 2014 when the highest reason for divorce was a lack of communication, the Bogor Government swiftly built places for family time to maintain communication between family members. However, since the last three years, there has been a social transformation in divorce, resulting in a change in the reasons for divorce, namely economic factors that led to disharmony.

When talking about economic problems, of course it cannot be separated from material issues. Although the Bogor City Government has a budget to build the City and its Human Resources, the high divorce rate cannot be minimized by providing compensation or material contributions to each head of household.

In addition, the Bogor City Government is considered to have been able to increase regional income and human resources, however, sometimes the fulfillment of the obligation of husbands for their wives is a relative value. It could be that the husband's monthly income actually fulfills household needs, but the wife feels insufficient due to the influence of the lifestyle in the surrounding environment.

For John Locke, what influences human development is the environment and the educational experience. He is the main figure in the flow of ideas initially founded "The school of British Empiricism" (British 
empiricism school). This stream is headquartered in the UK but its influence has reached the United States, thus giving birth to the flow of "Environmental Psychology". Lifestyle in Indonesian society is now very easy to adopt in everyday life, both positive and negative ways. The extent to which humans interact with the environment is the extent to which opportunities for educational influences are open to them.

Of the many factors causing divorce that occurred in the city of Bogor, which were registered at the Bogor City Religious Court, the case that most couples filed for divorce was the absence of harmony in the family, amounting to $67.1 \%$. The second most common is economic problems in the household amounting to $19.7 \%$, then a lack of responsibility equal to $10.7 \%$. Other causes of divorce with the lowest percentage were third party harassment, political, mental harm, underage marriage, and forced marriage. Throughout January 2019 to July 2019 there were no divorces for the reasons above.

\section{G. Religious Court and BP4}

One of the things that can suppress the divorce rate and problems in the household is the institutions in Indonesia, namely The Body for Guiding Marriage and Advisory for Divorce (Badan Pembinaan Perkawinan dan Penasihat Perceraian/BP4) and Religious Court. Since 2008, the Religious Courts have carried out their duties as one of the law enforcement instruments, namely carrying out mediation which is known as judicial mediation. All civil cases filed must go through mediation by judge mediators and non-judge mediators. The requirements for judges must be those who have attended the Special Education for Mediator Profession (PKPM) ${ }^{24}$ which is held by an institution accredited by the Supreme Court.

In carrying out their functions and duties, mediators must refer to the provisions of PerMA No. 1 of 2016 concerning Mediation Procedures in Courts and Mediator Guidelines prepared by the Supreme Court. However, in reality, the success of mediation in the Religious Courts is still below $10 \%$. This shows that the communication media in court have not been effective.

Table 7. Recapitulation of Respondents PA Mediation Reports 2017-201925

24 Training (Diklat) organized by an institution authorized by the Supreme Court to standardize mediators

25 Data source: Bogor City Religious Court Class 1A 


\begin{tabular}{cccccc}
\hline No & Year & $\begin{array}{c}\text { Number of } \\
\text { Cases That } \\
\text { Can Not } \\
\text { Be }\end{array}$ & $\begin{array}{c}\text { Number } \\
\text { of Cases } \\
\text { That Can } \\
\text { Be }\end{array}$ & \multicolumn{2}{c}{$\begin{array}{c}\text { Mediation } \\
\text { Settlement Report }\end{array}$} \\
\hline \multicolumn{5}{c}{ Fail } & Success \\
\hline 1 & 2017 & 1779 & 243 & 232 & 10 \\
2 & 2018 & 6434 & 290 & 265 & 25 \\
3 & 2019 & 4145 & 234 & 217 & 17
\end{tabular}

Table 7 explains that the success of mediation in handling divorce cases when compared to the number of cases mediated by it on average is still not very effective. In 2017 it was only $4.11 \%$ while in 2018 it rose to $8.6 \%$ because the number of cases mediated also increased. Then in 2019 the success of mediation decreased by $7.3 \%$ with the number of cases also decreasing. The data above shows that the average success of mediation is still below $10 \%$.

Based on table 7, it can also be seen that not all cases can be mediated. In fact, only a small part can be mediated. This can happen because the case filed by the litigant ends and is resolved by means of a verstek (absence of the opposing party). So, the standard of success in mediation in divorce cases with the withdrawal of the divorce suit is difficult to achieve.

Lawrence M. Friedman said that there are three elements ${ }^{26}$ that will make the legal system work well, namely the law enforcement, the rule of law, and the legal culture. Law enforcers are able to work well if the legal rules are clear and the people obey the law. If the three elements do not support each other, the law enforcement process can be less effective and not optimal.

The pattern of dispute resolution outside the court through mediation (sending hakam) is well known in the Islamic legal system. When there is a major conflict in the household that a husband and wife cannot resolve alone, Islam instructs both parties to send two hakam (peacemakers or mediators), with the intention of finding a way out. ${ }^{27}$

If the mediation is successful, the parties with the help of the mediator are obliged to formulate a written agreement in a peace agreement signed by the parties and the mediator, so that the case is declared to have been completed. If the mediation is unsuccessful, the mediator is obliged to declare that the mediation has not succeeded in reaching an agreement and notify this in writing to the case-examining judge. From the description above, the authors conclude that the mediation of divorce cases carried out at the Bogor City Religious Court has been

${ }^{26}$ Lawrence Friedman, Sistem Hukum Perspektif Ilmu Sosial. (Bandung: Nusa Media, 2011), p. 21.

27 Syahrizal Abbas, Mediasi dalam Hukum Syari'ah, Hukum Adat dan Hukum Nasional, (Jakarta: Kencana Prenada, 2011), cet, ke-2, p. 185. 
effective as seen from the mediation process in accordance with PERMA No. 1 of 2016.28

Laurence Boulle also said that there are four models for mediation, namely: settlement mediation, facilitative mediation, transformative mediation, and evaluative mediation.

a) Settlement mediation: compromise mediation which has the main objective of encouraging a compromise to be realized from the demands of the two conflicting parties.

b) Facilitative mediation: interest-based mediation and problem solving which aims to prevent conflicting parties from their positions and rigidly negotiate the needs and interests of the parties from their legal rights. ${ }^{29}$

c) Transformative mediation: mediation therapy and reconciliation. This mediation focuses on finding the causes of problems between the disputing parties. The process is to improve the relationship between them through recognition and empowerment as the basis for conflict resolution from existing disputes. ${ }^{30}$

d) Evaluative mediation or normative mediation is a mediation model that aims to reach an agreement based on the legal rights of the disputing parties in the area as anticipated by the court.

Religious Courts with their strategic functions, have an obligation to realize the four mediation models above. However, there were things that the Religious Courts deemed lacking in carrying out their duties.

Apart from the Religious Courts, another institution given the state's mandate to take care of divorce matters is BP4. In carrying out its duties, BP4 has two mediums of effort. The first effort, Preventive Efforts, an effort made by BP 4 before the marriage. This effort is very beneficial because in carrying out life after marriage, the husband and wife are equipped with knowledge about marriage life.

BP4 in each sub-district in Bogor City in embodying its preventive efforts in the form of:

a) Providing advice and counseling to the prospective bride and groom who will form a household.

${ }^{28}$ Indonesian Supreme Court Regulation (PERMA) No.1 of 2016 concerning Mediation Procedures in Courts was welcomed by the Indonesian Sharia Lawyers Association (APSI)

${ }^{29}$ Allan J. Stitt, Mediation: A Practical Guide (London: Routledge Cavendish, 2004), p. 2.

30 Robert A. Baruch Bush dan Josep P. Folger, The Promise of Mediation Transformative Approach to Conflict (USA: Willey, 2014), p. 41. 
b) Providing information that BP4 Kota Bogor is an institution that provides household consultation facilities that can be used by all people in the Bogor City Work Area.

c) Give lectures on marriage, the wisdom of marriage, and having a household according to the Shari'ah and Islamic religious guidance at the Walimatul Ursy event.

The second is curative efforts, which are activities carried out by the District BP4 to provide advice or mediators to married couples who are experiencing disputes and trying to find the best solution to the problems they face. The approach used by BP4 is not a juridical approach but instead emphasizes psychological and religious aspects. The implementation of curative efforts will be adjusted to the circumstances of the married couple. Even so, many couples were reluctant to come to BP4 and immediately register their cases at the Bogor City Religious Court.

Nowadays, the lawsuit divorce cases raise a big question, why are women (wives) now willing and brave to sue their husbands even though it is clear that the negative impact of divorce is not small, not only for themselves but also for children. The changes in this era bring an understanding of paradigm and value shifts. A psychologist, Nella Safitri, provides empathy for the main factors of cultural change in the case of a divorce case, including:

First, women today increasingly understand their rights in the household as wives. So there is an imbalance in rights and obligations or inadequacy where women do not feel willing if their rights are ignored and unfair. Second, economic independence for women that have influenced today's life. Because of the urgent need for many working women, this forms women's mindset that they have the strength to support themselves and their children. As a result, they are not ashamed of their status as widows. Third, women began to have a better understanding of religious knowledge, especially regarding the provisions for triple talaq which is sometimes uttered by the husband. When the husband has declared talaq repeatedly for three times, the wife believes that religion no longer allows them to be together. In this condition, if the husband does not feel that he has done that, contrary to the wife, then usually the wife comes forward to sue for divorce because she does not want to violate religious rules. Fourth, the wife does not accept her household hanging by her husband. In conclusion, the cause of lawsuit divorce is higher than talak divorce, including awareness of women's rights, gender equality, mainstream gender relations, and women's economic independence. 


\section{H. Conclusion}

Based on all the analysis and descriptions that have been stated previously, there are several conclusions to answer the problems in this study. They are as follows: First, the social transformation that occurs in the people of Bogor City affects family relations and divorce. The narrowing concept of family relations in urban areas makes the relationship between family members tenuous due to the husband and wife's business in fulfilling family needs. Shifting the functions and roles of family members, such as wives who are more responsible for managing the household than husbands, have positive and negative impacts. Nevertheless, in the end, the authors concluded that the negative impact would be more dominant to cause divorce against a double burden background on the part of the wife. The level of education, the workplace environment, the advancement of information and technology, and women's independence have an impact on social transformation.

Second, the factors that cause divorce in Bogor society both internally and externally are social, economic, irresponsible transformation between the two partners, age (maturity or immaturity), young marriage, forced marriage with a relatively low level of religious knowledge and education are the main drivers of the phenomenon of divorce in the city of Bogor. These will culminate in disharmony in the husband and wife relationship. Divorce in the Bogor City has also experienced a shift in pattern from divorce by talak, which was dominant in the beginning, to lawsuit divorce cases. This is motivated by the awareness of women's rights, gender equality, mainstream gender relations, and women's economic independence that have encouraged Indonesian women to make decisions that are fundamental to their lives.

In general, the main cause of divorce is a shortcoming in economic factors, such as the husband's ability to meet household needs which then develops into continuous quarrels and disputes. In addition, there is a form of wife nusyuz which discourages the husband's efforts in making a living. Divorce dominated by wives in the form of a lawsuit for divorce can also occur because of the lack of acceptance of husbands who tend to follow the lifestyle of the local community. Also, the lifestyle changes that increase syiqaq or fights in the household.

Third, responding to the social transformations that have continued to occur until now, it should be noted that massive divorces in Bogor will continue to experience repetition and the numbers will continue to increase. However, the phenomenon of divorce can change if there are systematic efforts through counseling and public awareness of the importance of maintaining the elements of sakinah, mawaddah, rahmah in household life. This is because the true motive of society lies in household 
life which is based on compassion, tolerance and respect for differences which are generally reflected in harmonious household life.

BP4 as a marriage advisory institution and fostering happy families, has carried out curative and preventive efforts to reduce the divorce rate as a mediator. The success of mediation in divorce cases compared to the number of cases mediated on average is still small, that is, below $10 \%$. However, consistency in the implementation of roles and functions is still maintained in every sub-district in Bogor City.

Likewise, the Bogor City Religious Court, which functions to adjudicate, guide, supervise, advise, and administrators for every legal case, especially divorce, does not automatically accept divorce applications from both husband and wife. Its role takes precedence with a mediator between the two parties to decide divorce cases when peaceful paths cannot be pursued. As a preventive form, marriage counseling is carried out by BP4 and the Bogor City Religious Court in collaboration with the Bogor City Health Office.

\section{Acknowledgments}

The authors would like to thank everyone who was involved from the beginning until the end of the process are muslim familes in Bogor, West Java. This includes our colleagues who gave feedbacks, as well as the editorial team and the reviewers who handled the manuscript and provided valuable insights in improving it further.

\section{J. Author Contributions Statement}

JM designed, conceptualized, and led the project. LS cleaned, prepared, and collected the data. JM and LS performed the statistical analysis and wrote the results, findings, and discussion. Both JM and LS wrote and edited the manuscript. WM and MM profreader and submitted the manuscript[.]

\section{REFERENCES}

Abbas, Syahrizal, Mediasi dalam Hukum Syari'ah, Hukum Adat dan Hukum Nasional, 2 ${ }^{\text {nd }}$ edition, Jakarta: Kencana Prenada, 2011.

Al-Ati, Hammudah Abd, Family Structure in Islam, (American Trust Publication, 1977)

Al-Sadlani, Shaleh bin Ghanim, Nusyuz, Konflik Suami Istri dan Penyelesaiannya, 2010.

Ali, Mohammad Daud, Hukum Islam dan Peradilan Agama, $2^{\text {nd }}$ edition, Jakarta: PT. Raja Grafindo Persada, 2002.

Bohannan, Paul, Divorce and After, America: Doubleday Books, 1970.

Bush, Robert A. Baruch dan Folger, Josep P., The Promise of Mediation Transformative Approach to Conflict, USA: Willey, 2014. 
Friedman, Lawrence, Sistem Hukum Perspektif Ilmu Sosial. Bandung: Nusa Media, 2011.

Gottman, John dan Claire, Joan De, Mengembangkan Kecerdasan Emosional Anak, Jakarta: PT. Gramedia Pustaka Utama, 2008.

Jaafar-Mohammad, Imani, dan Charlie Lehmann. "Women's Rights in Islam Regarding Marriage and Divorce." Journal of Law and Practice 4, no. 1 (1 Januari 2011): 1-13.

Jajuli, Sulaeman, Fenomena Al-Syiqaq dalam Putusan Perkawinan di Pengadilan Agama Kota Bogor, Bogor, Hasil penelitian tidak dipublikasikan (unpublished research result), 2016.

Kuzari, Achmad, Nikah Sebagai Perikatan, $1^{\text {st }}$ edition, Jakarta: PT Raja Grafindo Persada, 1995

Matondang, Armansyah. "Faktor-faktor yang Mengakibatkan Perceraian dalam Perkawinan." JPPUMA: Jurnal Ilmu Pemerintahan dan Sosial Politik UMA (Journal of Governance and Political Social UMA) 2, no. 2 (1 Desember 2014):

$141-50$. https://doi.org/10.31289/jppuma.v2i2.919

Nurhadi, Nurhadi, dan Mawardi Dalimunthe. "Concept of Maqasyid Syariah Family Sakinah In The Al-Misbah Tafsir by Muhammad Quraish Shihab." AKADEMIKA: Jurnal Pemikiran Islam 24, no. 1 (18 September 2019):

$165-86$.

https://doi.org/10.32332/akademika.v24i1.1619

Noller, Patricia, Marital Conflict, Australian Institute of Family Studies, Journal of Family Matters No.55 Autumn, 2000.

Qardhawi, Muhammad Yusuf, Halal Haram Dalam Islam, terj. Muammal Hamidi, Surabaya: PT Bina Ilmu, 1980.

Sabiq, Sayyid, Figh Sunnah, 1'st edition, volume 2, Kairo: Daar al-Fath, 2000. Septiarti, S. Wisni. "Transformasi Sosial Masyarakat Dalam Perspektif Strukturalisme - Fungsionalisme Suatu Tinjauan Sosiologis." Jurnal Cakrawala Pendidikan 3, no. XIII (1994): 127-38. https://doi.org/10.21831/cp.v3i3.9153

Stitt, Allan J., Mediation: A Practical Guide, London: Routledge Cavendish, 2004.

Syarifuddin, Amir, Hukum Perkawinan Islam di Indonesia: Antara Figh Munakahat dan Undang-Undang Perkawinan, Jakarta: Prenada Media, 2015.

Syarifuddin, Amir, Garis-Garis Besar Fiqh, $1^{\text {st }}$ edition, Bogor: Kencana Prenada Media, 2003.

Wijayati, Mufliha, dan Aden Rosadi. "Women Before The Law: Between Justice and Certainty: Notes on Divorce Settlement Case Due to Domestic Violencein Metro Religious Court." AKADEMIKA: Jurnal Pemikiran Islam 25, no. 1 (Juni 2020): 209-34. https://doi.org/10.32332/akademika.v25i1.1974 